\title{
Effect of SCH442416 on glutamate uptake in retinal Müller cells at increased hydrostatic pressure
}

\author{
YONG LI ${ }^{1 *}$, XIAOHONG LIU ${ }^{2 *}$, SHOUYUE HUANG ${ }^{2}$, PING HUANG $^{3}$ and YISHENG ZHONG ${ }^{2}$ \\ ${ }^{1}$ Department of Ophthalmology, Tongren Hospital Affiliated Medical School, Shanghai Jiaotong University, Shanghai 200336; \\ ${ }^{2}$ Department of Ophthalmology, Ruijin Hospital Affiliated Medical School; ${ }^{3}$ Shanghai Key Laboratory for Bone and Joint Diseases, \\ Shanghai Institute of Traumatology and Orthopaedics, Ruijin Hospital Affiliated Medical School, \\ Shanghai Jiaotong University, Shanghai 200025, P.R. China
}

Received August 27, 2014; Accepted May 13, 2015

DOI: $10.3892 / \mathrm{mmr} .2015 .3882$

\begin{abstract}
The $A_{2 A}$ receptor $\left(A_{2 A} R\right)$ antagonist has been considered as an attractive option to improve the treatment of neurological disorders, and the function of $\mathrm{A}_{2 \mathrm{~A}} \mathrm{R}$ antagonist may inhibit the release of glutamate and prevent neuron damage. The aim of the present study was to investigate whether SCH442416 can modulate the glutamate uptake in retinal Müller cells under increased hydrostatic pressure. The levels of glutamine synthetase (GS) and glutamate aspartate transporter (GLAST) were assessed in retinal Müller cells under $40 \mathrm{mmHg}$ pressure for $24 \mathrm{~h}$ using reverse transcription-quantitative polymerase chain reaction and western blotting, and a glutamate uptake assay was performed using a scintillation counting method. Following treatment of the Müller cells with $100 \mathrm{nM}$ SCH442416 under $40 \mathrm{mmHg}$ pressure for $24 \mathrm{~h}$, the mRNA and protein expression levels of GS and GLAST, and glutamate uptake activity were investigated. Under $40 \mathrm{mmHg}$ pressure, the expression levels of GS and GLAST in the Müller cells, and glutamate uptake activity were significantly reduced. Treatment with SCH442416 significantly ameliorated the decreased expression levels of GS and GLAST, and improved the glutamate uptake activity in the retinal Müller cells exposed to $40 \mathrm{mmHg}$ pressure,
\end{abstract}

Correspondence to: Professor Yisheng Zhong, Department of Ophthalmology, Ruijin Hospital Affiliated Medical School, Shanghai Jiaotong University, 197 Ruijin Er Road, Shanghai 200025, P.R. China

E-mail: yszhong68@126.com

Ms. Ping Huang, Shanghai Key Laboratory for Bone and Joint Diseases, Shanghai Institute of Traumatology and Orthopaedics, Ruijin Hospital Affiliated Medical School, Shanghai Jiaotong University, 197 Ruijin No. 2 Road, Shanghai 200025, P.R. China E-mail: pinghpingh@126.com

*Contributed equally

Key words: Müller cells, SCH442416, glutamine synthetase, glutamate aspartate transporter, glutamate uptake resulting in increased expression levels of GS and GLAST, and increased glutamate uptake activity in the Müller cells under pressure. These results suggested that SCH442416 may be a potential candidate as a beneficial neuroprotective agent for the treatment of glaucoma by accelerating the clearance of extracellular glutamate.

\section{Introduction}

Glaucoma is the leading cause of blindness worldwide and is one of the most common neurodegenerative diseases, which is characterized by the irreversible and progressive loss of retinal ganglion cells (RGCs) and damage to the optic nerve, usually in response to abnormally increased intraocular pressure (1-4).

Müller cells are the principal glia of the retina, and the predominant function of Müller cells is to regulate extracellular glutamate levels (5). Glutamate, a normal constituent of the retina, is taken up by Müller cells and is converted to glutamine, which is taken up the neurons. The neurons use glutamine to synthesize glutamate for neurotransmission (5). Müller cells are involved in glutamate metabolism via the glutamate aspartate transporter (GLAST) and glutamine synthetase (GS). The GLAST is responsible for the transport of glutamate into Müller cells and GS is the enzyme, which converts glutamate into glutamine inside the Müller cells (6). Increased levels of extracellular glutamate have been reported in a primate model of glaucoma and in human patients with glaucoma (7). This increase in extracellular glutamate levels is predominantly due to the downregulation of GLAST (8). Excess glutamate release is involved in glaucomatous neuropathy, which causes excitotoxic damage to the RGCs through the activation of ionotropic and metabotropic glutamate receptors $(9,10)$. Consequently, the efficient removal of glutamate from the extracellular space is required for the maintenance of a healthy retina.

Adenosine is a ubiquitous local modulator, which regulates various physiological and pathological functions by stimulating membrane receptors. Biochemical, pharmacological, and molecular investigations have identified four adenosine receptor subtypes, $A_{1}, A_{2 A}, A_{2 B}$ and $A_{3}$ (11). There is increasing evidence that adenosine is an important intracellular mediator in the retina and has considerable potential to protect retinal 
neurons (12-14). Previously, an $\mathrm{A}_{2 \mathrm{~A}}$ receptor $\left(\mathrm{A}_{2 \mathrm{~A}} \mathrm{R}\right)$ antagonist has been suggested as an attractive option to improve the treatment of neurological disorders, including Parkinson's disease, Huntington's disease and Alzheimer's disease $(15,16)$. The function of the $\mathrm{A}_{2 \mathrm{~A}} \mathrm{R}$ antagonist may be to inhibit the release of glutamate and prevent damage of the neuron (17). The aim of the present study was to investigate whether the $\mathrm{A}_{2 \mathrm{~A}} \mathrm{R}$ antagonist, SCH442416, modulates the expression levels of GS and GLAST, and the uptake of glutamate in retinal Müller cells exposed to increased hydrostatic pressure.

\section{Materials and methods}

Pressure device. The pressure device used in the present study was described in detail in our previous study (18). Briefly, a T75 culture flask (Shanghai Jun Sheng Biological Technology Co., Ltd., Shanghai, China) was equipped with a manometer (Fang Jun Instrument Co., Ltd., Shanghai, China) and placed in an incubator, maintained at $37^{\circ} \mathrm{C}$, as the pressure device. An air mixture of $95 \%$ air and $5 \% \mathrm{CO}_{2}$ was pumped into the flasks to obtain pressure. The pressure level of the model was $40 \mathrm{mmHg}$, as in our previous investigation (18), which was adjusted every $4 \mathrm{~h}$. The total duration of the induced pressure was $24 \mathrm{~h}$. In the experiments, several precautions were made to limit artifacts from the experimental method. Laboratory film (Pechiney, Stamford, CT, USA) was used to seal the interfaces and, to avoid artifacts caused by 'on-off' changes in pressure, all operations involving the refreshment of medium or adjustment of pressure were performed within a 5 min period.

Müller cell culture. All investigations involving animals in the present study were performed in strict accordance with the Association for Research in Vision and Ophthalmology Statement for the Use of Animals in Ophthalmic and Vision Research (19). The present study was approved by the Ethics Committee of Ruijin Hospital, Shanghai Jiaotong University (Shanghai, China). The primary culture of retinal Müller cells was generated, as previously described (18). Briefly, the retinas of 80 newborn (2-5 days old, male and females) Sprague-Dawley rats, obtained from Shanghai Slack Laboratory Animal Co., Ltd. (Shanghai, China) were collected following sacrifice by intraperitoneal of $30 \%$ chloral hydrate (500 mg/kg; Chemical Reagent Co., Ltd., Shanghai, China). For each experiment, the retinas $(n=20)$ were dissected and stored on ice in D-Hank's solution (Anresco LLC, Solon, $\mathrm{OH}$, USA). The tissue was dissociated by centrifugation at room temperature for $5 \mathrm{~min}$ at $600 \mathrm{x} \mathrm{g}$ and was incubated for $15 \mathrm{~min}$ at $37^{\circ} \mathrm{C}$ in phosphate-buffered saline (PBS), containing $0.125 \%$ trypsin (Anresco LLC). Finally, the cell suspension was cultured in $\mathrm{T} 75$ culture flasks at $37^{\circ} \mathrm{C}$ in humidified air containing $5 \% \mathrm{CO}_{2}$. Following the initial outgrowth, the cell culture medium was replaced every $48 \mathrm{~h}$ and maintained in Dulbecco's modified Eagle's medium (DMEM; Gibco Life Technologies, Carlsbad, CA, USA), supplemented with $2 \mathrm{mM}$ glutamine, $100 \mathrm{U} / \mathrm{ml}$ penicillin, $100 \mu \mathrm{g} / \mathrm{ml}$ streptomycin and $10 \%$ fetal bovine serum (Sijiqing, Zhejiang, China).

Following culture for 5-8 days, the flasks were agitated at $37^{\circ} \mathrm{C}$ for $1 \mathrm{~h}$ at $100 \mathrm{rpm}$ and the cell culture medium was refreshed. By agitating the plates, other types of cell, including microgilal cells and RGCs, which were initially adhered to the surface of the Müller cells, were rinsed off with DMEM to obtain a purified cell population. For passage, the cell cultures were incubated at $37^{\circ} \mathrm{C}$ with PBS, containing $0.125 \%$ trypsin. The Müller cells were identified via GS and glial fibrillary acidic protein (GFAP) staining using indirect immunofluorescence. The cells were fixed with $4 \%$ paraformaldehyde at room temperature for $10 \mathrm{~min}$ and were incubated with $0.3 \%$ Triton $\mathrm{X}-100$ at $37^{\circ} \mathrm{C}$ for $10 \mathrm{~min}$. The cells were washed three times (10 min/wash) with PBS, blocked with $10 \%$ goat serum in PBS and subsequently incubated with the rabbit anti-rat polyclonal antibody against GS (1:5,000; ab49873; Abcam, Cambridge, MA, USA) and the mouse anti-rat monoclonal antibody against GFAP (1:200; ab4648, Abcam) as an identity marker for Müller cells. The cells were then incubated overnight at $4^{\circ} \mathrm{C}$. The following day, the cells were incubated with the secondary donkey anti-rabbit IgG-Cy3 polyclonal antibody (1:200; 406402; BioLegend, Inc., San Diego, CA, USA) at $37^{\circ} \mathrm{C}$ in darkness for $1 \mathrm{~h}$. Following three washes with PBS, the cells on the coverslips were mounted on glass slides with Histomount (Invitrogen Life Technologies, Carlsbad, CA, USA). The cells were viewed under an Axio microscope (Zeiss, Oberkochen, Germany), and images were acquired with a digital camera (Canon, Tokyo, Japan).

Drug treatment. The $\mathrm{A}_{2 \mathrm{~A}}$ receptor antagonist, 2-(2-Furan yl)-7-[3-(4-methoxyphernyl)propyl]-7H-pyrazolo[4,3-e] (1 $, 2,4)$ triazolo[1,5-c]pyrimidin-5-amine (SCH442416), was purchased from Tocris Bioscience (Ellisville,. MO, USA). The experiments were performed following the second passage, when cell confluence was $80-90 \%$. The cells were cultured in serum-free medium and divided into the following three groups: Normal culture group; $40 \mathrm{mmHg}$ pressure culture group; $40 \mathrm{mmHg}$ pressure + $100 \mathrm{nM} \mathrm{SCH} 442416$ culture group. The Müller cells in the three groups were continually cultured at $37^{\circ} \mathrm{C}$ for another $24 \mathrm{~h}$. The concentration of SCH442416 used in the present study was selected, according to preliminary experiments (Data not shown).

Reverse transcription quantitative polymerase chain reaction $(R T-q P C R)$. The cells were collected and used for total RNA preparations. The total RNA was reverse-transcribed into cDNA using a previously described method (20) and the Invitrogen Reverse Transcription kit (Invitrogen Life Technologies). The PCR solution contained $2 \mu 1 \mathrm{cDNA}$, specific primers (1 $\mu \mathrm{M}$ each) and $10 \mu \mathrm{l}$ QuantiTect SYBR Green PCR kit reagent (Qiagen, Hilden, Germany) in a final volume of $20 \mu \mathrm{l}$. The following primer pairs from Sangon Biotech Co., Ltd. (Shanghai, China) were used: GS, sense 5'-CCGCTCTTCGTCTCGTTC-3' and anti-sense 5'-CTGCCTGATGCCTTTGTT-3'; GLAST, sense 5'-CCTATGTGGCAGTCGTTT-3' and anti-sense 5'-CTGTGATGGGCTGGCTAA-3'; and $\beta$-actin, sense 5'-GCGCTCGTCGTCGACAACGG-3' and anti-sense 5'-GTGTGGTGCCAAATCTTCTCC-3'. The PCR parameters were as follows: Initial denaturation at $94^{\circ} \mathrm{C}$ for $5 \mathrm{~min}$; amplification and quantification, 40 cycles at $94^{\circ} \mathrm{C}$ for $30 \mathrm{sec}$, $55^{\circ} \mathrm{C}$ for $30 \mathrm{sec}$, and $72^{\circ} \mathrm{C}$ for $30 \mathrm{sec}$; melting curve, $55^{\circ} \mathrm{C}$ with the temperature gradually increased up to $95^{\circ} \mathrm{C}$. The mRNA expression levels were normalized against the levels of $\beta$-actin, as described previously (20). 
Western blot analysis. The cultured cells in the samples from the different groups were washed twice with PBS. The total protein was extracted with the EpiQuik Whole Cell Extraction kit (Epigentek, Farmingdale, NY, USA) according the manufacturer's instructions. Protein concentration was determined by the radioimmunoprecipitation buffer assay (Cell Signaling Technology, Inc., Danvers, MA, USA) and lysed in 2X Laemmli buffer (Bio-Rad Laboratories, Inc., Hercules, CA, USA). The protein extracts $(40 \mu \mathrm{g})$ were boiled for $10 \mathrm{~min}$ and centrifuged at $14,000 \mathrm{x} \mathrm{g}$. The proteins were separated on $12 \%$ SDS-PAGE gels (Sigma-Aldrich, St. Louis, MO, USA) and were transferred onto polyvinylidine fluoride membranes (EMD Millipore, Billerica, MA, USA). The membranes were soaked in Tris-buffered saline (Sigma-Aldrich), containing $20 \mathrm{mmol} / \mathrm{l}$ Tris-Cl, $140 \mathrm{mmol} / \mathrm{l} \mathrm{NaCl}$ (pH 7.5), with 5\% non-fat milk and $0.1 \%$ Tween-20 (Sigma-Aldrich) for $1 \mathrm{~h}$ at room temperature. The membranes were incubated with primary rabbit anti-rat polyclonal antibodies against GS (ab49873; 1:10,000; Abcam) and GLAST (ab416; 1:200; Abcam) overnight at $4^{\circ} \mathrm{C}$. Rabbit anti-rat polyclonal anti-GAPDH antibody (ab37168; 1:10,000; Abcam) was used as a reference to normalize the intensities of the immunoreactions with different antibodies. Following several washes with PBS, the membranes were incubated with horseradish peroxidase-conjugated goat anti-rabbit immunoglobulin G (A20019; 1:2,000; Invitrogen Life Technologies) for $1 \mathrm{~h}$ at room temperature and visualized using enhanced chemofluorescence reagent (Beyotime Institute of Biotechnology, Haimen, China). Images were captured using ImageQuant Las 4000 mini (GE Healthcare Life Sciences, Kochi, Japan) and the protein bands were quantitatively analyzed using ImagePro Plus image analysis software v.7.0 (Zeiss).

Glutamate uptake assay. The cultured Müller cells in the treatment groups were washed in PBS and pre-incubated in Kreb's solution (Sigma-Aldrich), containing $119 \mathrm{mM} \mathrm{NaCl}$, $4.7 \mathrm{mM} \mathrm{KCl}, 1.2 \mathrm{mM} \mathrm{KH}_{2} \mathrm{PO}_{4}, 25 \mathrm{mM} \mathrm{NaHCO}, 2.5 \mathrm{mM} \mathrm{CaCl}_{2}$ and $1 \mathrm{mM} \mathrm{MgCl}_{2}$, for $30 \mathrm{~min}$ at $37^{\circ} \mathrm{C}$. The Müller cells were then exposed to $0.5 \mu \mathrm{Ci} / \mathrm{ml} \mathrm{L}-[2,3-3 \mathrm{H}]$ glutamate (New England Nuclear, Boston, MA, USA) and $10 \mathrm{mmol} / \mathrm{l}$ unlabeled glutamate for $60 \mathrm{~min}$ at $37^{\circ} \mathrm{C}$. The reaction was terminated by washing the cells three times with ice-cold PBS. The Müller cells were subsequently lysed in PBS and small aliquots $(20 \mu \mathrm{l})$ were removed from each well for the determination of protein content. The L-[2,3-3H] glutamate content of the lysates were determined by scintillation counting (Triathler Scintillator; Beijing Huaruison Science and Technology Development Co., Ltd., Beijing, China). All experiments were performed in triplicate for each of the four separate cell preparations.

Statistical analysis. The data are expressed as the mean \pm standard deviation. All analyses were performed using SPSS 19.0 statistical software (IBM SPSS, Chicago, IL, USA). The data were analyzed using one-way analysis of variance, followed by a least significant difference test. $\mathrm{P}<0.05$ was considered to indicate a statistically significant difference.

\section{Results}

Effect of SCH442416 on the mRNA expression levels of GS and GLAST in the cultured retinal Müller cells under pressure
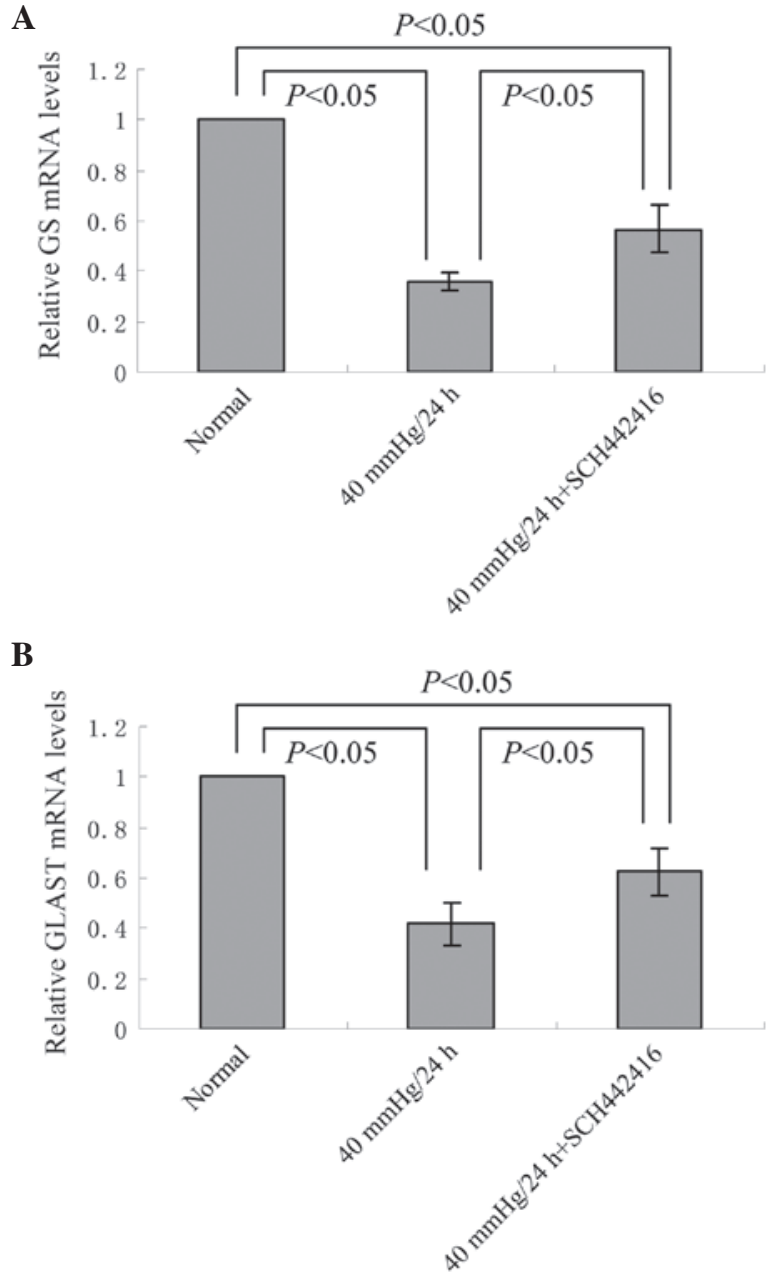

Figure 1. Reverse transcription-quantitative polymerase chain reaction analysis of the mRNA expression levels of (A) GS and (B) GLAST in retinal Müller cells cultured with or without SCH 442416, subjected to $40 \mathrm{mmHg}$ pressure conditions for $24 \mathrm{~h}$. Each measurement was performed in triplicate for each of four separate cell preparations. The mRNA expression levels of GS and GLAST were significantly decreased in the Müller cells cultured with or without SCH442416 under $40 \mathrm{mmHg}$ pressure, compared with the normal control. The mRNA expression levels of GS and GLAST in the $40 \mathrm{mmHg}$ pressure $+\mathrm{SCH} 442416$ culture group were significantly higher, compared with those in the $40 \mathrm{mmHg}$ pressure culture group. The data are expressed as the mean \pm standard deviation. GS, glutamine synthetase; GLAST, glutamate aspartate transporter.

conditions. The mRNA expression levels of GS and GLAST of the retinal Müller cells incubated in serum-free medium, in the presence or absence of SCH442416, under $40 \mathrm{mmHg}$ pressure for $24 \mathrm{~h}$ was analyzed using RT-qPCR. Compared with the normal culture group, the mRNA expression levels of GS and GLAST were significantly decreased in the Müller cells cultured with or without SCH442416 under $40 \mathrm{mmHg}$ pressure conditions $(\mathrm{P}<0.05$; Fig. 1). However, the mRNA expression levels of GS and GLAST in the $40 \mathrm{mmHg}$ pressure + $100 \mathrm{nM} \mathrm{SCH442416}$ culture group were significantly higher, compared with those in the $40 \mathrm{mmHg}$ pressure culture group $(\mathrm{P}<0.05$; Fig. 1$)$.

Effect of SCH442416 on the protein expression levels of GS and GLAST in the cultured retinal Müller cells under pressure conditions. The protein expression levels of GS and GLAST in retinal Müller cells were compared between the normal control group and the groups under $40 \mathrm{mmHg}$ pres- 
A

GS

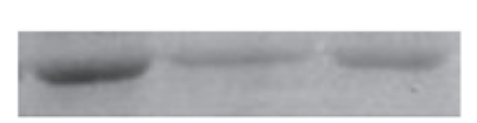

$42 \mathrm{kDa}$

\section{GLAST}

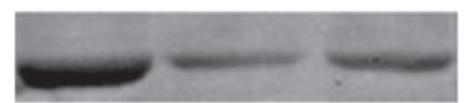

$60 \mathrm{kDa}$

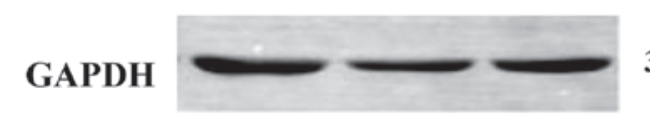

$36 \mathrm{kDa}$

B

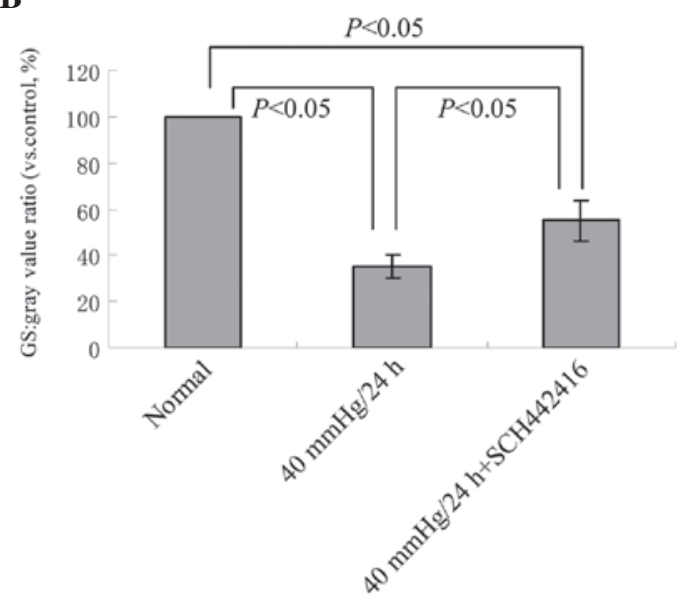

$\mathbf{C}$

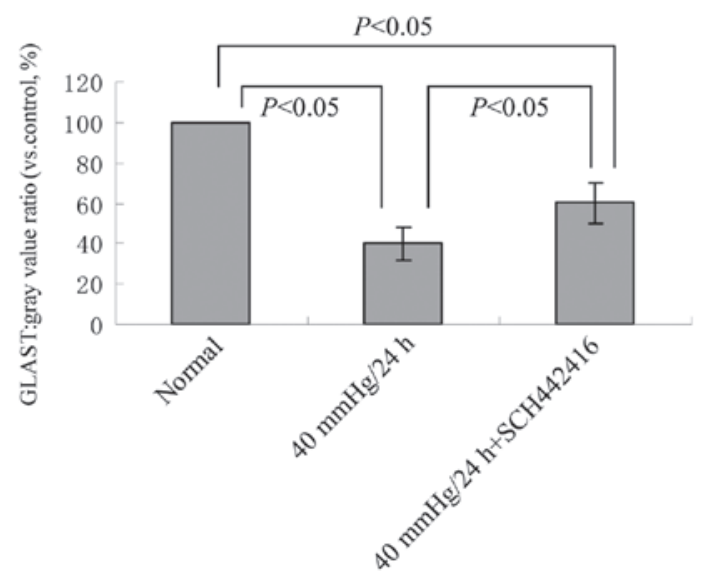

Figure 2. (A) Western blot analysis of the protein expression levels of GS and GLAST in retinal Müller cells cultured with or without SCH 442416 subjected to $40 \mathrm{mmHg}$ pressure for $24 \mathrm{~h}$. Each measurement was performed in triplicate for each of four separate cell preparations. (B and C) Protein expression levels of GS and GLAST were significantly decreased in the Müller cells cultured with or without SCH442416 under $40 \mathrm{mmHg}$ pressure. The protein expression levels of GS and GLAST in the $40 \mathrm{mmHg}$ pressure $+\mathrm{SCH} 442416$ culture group were significantly higher, compared with the $40 \mathrm{mmHg}$ pressure culture group. The data are expressed as the mean \pm standard deviation. $\mathrm{N}$, normal culture group; $\mathrm{P}, 40 \mathrm{mmHg}$ pressure culture group; $\mathrm{P}+\mathrm{S}, 40 \mathrm{mmHg}$ pressure $+100 \mathrm{nM}$ SCH442416 culture group. GS, glutamine synthetase; GLAST, glutamate aspartate transporter.

sure for $24 \mathrm{~h}$, in the presence or absence of SCH442416. Western blotting revealed that the expression levels of GS and GLAST were significantly decreased in the Müller cells cultured with or without SCH442416 under $40 \mathrm{mmHg}$ pressure, compared with the normal culture $(\mathrm{P}<0.05$; Fig. 2$)$. However, the protein expression levels of GS and GLAST in

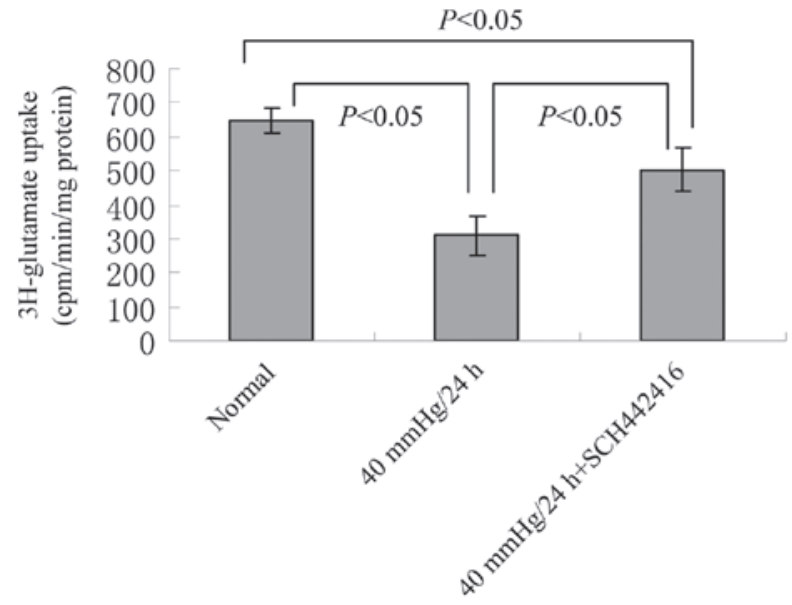

Figure 3. Effect of SCH442416 on the activity of glutamate uptake in cultured retinal Müller cells under pressure conditions. Each measurement was performed in triplicate for each of the four separate cell preparations. The glutamate uptake activity was significantly decreased in the Müller cells cultured with or without $\mathrm{SCH} 442416$ under $40 \mathrm{mmHg}$ pressure. The glutamate uptake activity in the $40 \mathrm{mmHg}$ pressure $+\mathrm{SCH} 442416$ culture group was significantly higher, compared with the $40 \mathrm{mmHg}$ pressure culture group. The data are expressed as the mean \pm standard deviation.

the $40 \mathrm{mmHg}$ pressure $+100 \mathrm{nM} \mathrm{SCH} 442416$ group were significantly higher, compared with the $40 \mathrm{mmHg}$ pressure group $(\mathrm{P}<0.05$; Fig. 2$)$.

Effect of SCH442416 on glutamate uptake activity in the cultured retinal Müller cells under pressure conditions. A glutamate uptake assay was performed using a scintillation counting method to determine the $3 \mathrm{H}$-glutamate content in the lysates. Compared with the normal culture group, the glutamate uptake activity was significantly decreased in the Müller cells cultured with or without SCH442416 under $40 \mathrm{mmHg}$ pressure $(\mathrm{P}<0.05$; Fig. 3). However, the glutamate uptake activity in the $40 \mathrm{mmHg}$ pressure $+100 \mathrm{nM} \mathrm{SCH} 442416$ culture group was significantly higher, compared with that in the $40 \mathrm{mmHg}$ pressure culture group $(\mathrm{P}<0.05$; Fig. 3$)$.

\section{Discussion}

The present study used a novel pressure model, which involved the culture of retinal Müller cells under hydrostatic pressure. The hydrostatic pressure used in this model was adjusted to $40 \mathrm{mmHg}$, a moderately elevated pressure, which often occurs in chronic glaucoma models (21). In the present study, several precautions and design considerations were made to limit artifacts from the experimental procedure. Laboratory film was used to seal interfaces and, to avoid artifacts from 'on-off' changes in pressure, replacements of media or adjustments of pressure were completed without delay. Our previous study also revealed that this pressure model was effective (18).

Glutamate acts as a neurotransmitter in the normal retina. However, excessive stimulation of glutamate receptors can result in excitotoxicity (22). Intraocular glutamate can cause severe degeneration of the inner retinal layers, particularly the RGC layer (23). These findings support the hypothesis that increased extracellular glutamate concentration or decreased glutamate clearance results in excitotoxic damage and may contribute to 
the pathogenesis of glaucoma (24-26). Müller cells maintain an close association with retinal neurons and are important in regulating extracellular glutamate levels. Glutamate is transported into the Müller cells via GLAST and is catalyzed by GS to the non-toxic amino acid, glutamine. Glutamate transport is the only mechanism for removing glutamate from the extracellular fluid (27). It las been suggested that functional impairment of glutamate transporters may be involved in excitotoxicity and contribute to the pathogenesis of glaucoma $(28,29)$. The present study indicated that Müller cells treated with $40 \mathrm{mmHg}$ pressure decreased the expression levels of GS and GLAST, and reduced the L-[2,3-3H] glutamate uptake activity, which was consistent with the results of previous studies $(30,31)$.

$\mathrm{A}_{2 \mathrm{~A}} \mathrm{R}$ is expressed in the inner nuclear layer, RGC layer and, less prominently, in the outer nuclear layer (32-34). Previous studies have demonstrated that $\mathrm{A}_{2 \mathrm{~A}} \mathrm{R}$ antagonists can enhance the recovery of retinal function following ischemia attack $(35,36)$. The present study demonstrated that the $A_{2 A} R$ antagonist, SCH442416, increased the expression levels of GS and GLAST, and increased the L-[2,3-3H] glutamate uptake activity in Müller cells subjected to $40 \mathrm{mmHg}$ pressure. This suggested that the $\mathrm{A}_{2 \mathrm{~A}} \mathrm{R}$ antagonist may protect RGCs by accelerating the clearance of extracellular glutamate in retina.

Collectively, the data of the present study suggested that Müller cells treated with $40 \mathrm{mmHg}$ pressure decreased the expression levels of GS and GLAST, and reduced glutamate uptake activity. By contrast, SCH442416 increased the expression levels of GS and GLAST, and increased glutamate uptake activity in the Müller cells under pressure, therefore, the SCH442416 A $\mathrm{A}_{2 \mathrm{~A}} \mathrm{R}$ antagonist may be a potential candidate as a neuroprotective agent for the treatment of glaucoma by accelerating the clearance of extracellular glutamate. Further investigations are required to confirm these effects in animal experiments.

\section{Acknowledgements}

This study was funded by the National Natural Science Foundation of China (grant no. 81371014) and the Shanghai 'Science and Technology Innovation Actioßn Plan' Basic Research Key Project (grant nos. 11JC1407700 and 11JC1407701).

\section{References}

1. Foster PJ, Buhrmann R, Quigley HA and Johnson GJ: The definition and classification of glaucoma in prevalence surveys. Br J Ophthalmol 86: 238-242, 2002.

2. Kwon YH, Fingert JH, Kuehn MH and Alward WL: Primary open angle glaucoma. N Engl J Med 360: 1113-1124, 2009.

3. Quigley HA: Glaucoma. Lancet 377: 1367-1377, 2011.

4. Sommer A: Intraocular pressure and glaucoma. Am J Ophthalmol 107: 186-188, 1989.

5. Newman E and Reichenbach A: The Müller cell: A functional element of the retina. Trends Neurosci 19: 307-312, 1996.

6. Pow DV and Crook DK: Direct immunocytochemical evidence for the transfer of glutamine from glial cells to neurons: Use of specific antibodies directed against the D-steroisomers of glutamate and glutamine. Neuroscience 70: 295-302, 1996.

7. Dreyer EB: A proposed role for excitotoxicity in glaucoma. J Glaucoma 7: 62-67, 1998.

8. Naskar R, Vorwerk CK and Dreyer EB: Concurrent downregulation of a glutamate transporter and receptor in glaucoma. Invest Ophthamol Vis Sic 41: 1940-1944, 2000.

9. Zhong YS, Leung CK and Pang CP: Glial cells and glaucomatous neuropathy. Chin Med J 120: 326-335, 2007.
10. Kawasaki A, Otori Y and Barnstable CJ: Müller cell pretection of rat retinal ganglion cells from glutamate and nitric oxide neurotoxicity. Invest Ophthamol Vis Sic 41: 3444-3450, 2000.

11. Fredholm BB, IJzerman AP, Jacobson KA, Klotz KN and Linden J: Nomenclature and classification of adenosine receptors. Pharmacol Rev 53: 527-552, 2001.

12. Ghiardi GJ, Gidday JM and Roth S: The purine nucleoside adenosine in retinal ischemia-reperfusion injury. Vision Res 39: 2519-2535, 1999

13. Larsen AK and Osborne NN: Involvement of adenosine in retinal ischemia. Studies on the rat. Invest Ophthalmol Vis Sci 37: 2603-2611, 1996

14. Li B and Roth S: Retinal ischemic preconditioning in the rat: Requirement for adenosine and repetitive induction. Invest Ophthalmol Vis Sci 40: 1200-1216, 1999.

15. Wang Z, Che PL, Du J, Ha B and Yarema KJ: Static magnetic field exposure reproduces cellular effects of the Parkinson's disease drug candidate ZM241385. PLoS One 5: e13883, 2010.

16. Tarazi FI, Sahli ZT, Wolny M and Mousa SA: Emerging therapies for Parkinson's disease: From bench to bedside. Pharmacol Ther 144: 123-133, 2014.

17. Pepponi R, Ferrante A, Ferretti R, et al: Region-specific neuroprotective effect of ZM 241385 towards glutamate uptake inhibition in cultured neurons. Eur J Pharmacol 617: 28-32, 2009.

18. Yu J, Zhong Y, Cheng Y, et al: Effect of high hydrostatic pressure on the expression of glutamine synthetase in rat retinal Müller cells cultured in vitro. Exp Ther Med 2: 513-516, 2011.

19. Statement for the Use of Animals in Ophthalmic and Visual Research. The Association for Research in Vision and Ophthalmology, Rockville, 2015.

20. Pfaffl MW: A new mathematical model for relative quantification in real-time RT-PCR. Nucleic Acids Res 29: e45, 2001.

21. Goldblum D and Mittag T: Prospects for relevant glaucoma models with retinal GC damage in the rodent eye. Vision Res 42: 471-478, 2002.

22. Vizi ES, Kisfali $M$ and Lórincz T: Role of nonsynaptic GluN2B-containing NMDA receptors in excitotoxicity: evidence that fluoxetine selectively inhibits these receptors and may have neuroprotective effects. Brain Res Bull 93: 32-38, 2013.

23. Siliprandi R, Canella R, Carmignoto G, Schiavo N, Zanellato A, Zanoni R and Vantini G: N-methyl-D-aspartate-induced neurotoxicity in the adult rat retina. Vis Neurosci 8: 567-573, 1992.

24. Dreyer EB, Zurakowski D, Schumer RA, Podos SM and Lipton SA: Elevated glutamate in the vitreous body of humans and monkeys with glaucoma. Arch Ophthalmol 114: 299-305, 1996.

25. Dreyer EB and Grosskreutz CL: Excitatory mechanisms in retinal ganglion cell death in primary open angle glaucoma (POAG). Clin Neurosci 4: 270-273, 1997.

26. Vorwerk CK, Gorla MS and Dreyer EB: An experimental basis for implicating excitotoxicity in glaucomatous optic neuropathy. Surv Ophthalmol 43 (Suppl 1): S142-S150, 1999.

27. Danbolt NC: Glutamate uptake. Prog Neurobiol 65: 1-105, 2001.

28. Naskar R, Vorwerk CK and Dreyer EB: Concurrent downregulation of a glutamate transporter and receptor in glaucoma. Invest Ophthalmol Vis Sci 41: 1940-1944, 2000.

29. Martin KR, Levkovitch-Verbin H, Valenta D, Baumrind L, Pease ME and Quigley HA: Retinal glutamate transporter changes in experimental glaucoma and after optic nerve transection in the rat. Invest Ophthalmol Vis Sci 43: 2236-2243, 2002.

30. Ishikawa M, Yoshitomi T, Zorumski CF and Izumi Y: Effects of acutely elevated hydrostatic pressure in the rat ex vivo retinal preparation. Invest Ophthalmol Vis Sci 51: 6414-6423, 2010.

31. Ishikawa $M$, Yoshitomi $\mathrm{T}$, Zorumski $\mathrm{CF}$ and Izumi $\mathrm{Y}$ : Downregulation of glutamine synthetase via GLAST suppression induces retinal axonal swelling in a rat ex vivo hydrostatic pressure model. Invest Ophthalmol Vis Sci 52: 6604-6616, 2011.

32. Kvanta A, Seregard S, Sejersen S, Kull B and Fredholm BB: Localization of adenosine receptor messenger RNAs in the rat eye. Exp Eye Res 65: 595-602, 1997.

33. Blazynsk C: Discrete distributions of adenosine receptors in mammalian retina. J Neurochem 54: 648-655, 1990.

34. Crooke A, Guzmán-Aranguez A, Peral A, Abdurrahman MK and Pintor J: Nucleotides in ocular secretions: Their role in ocular physiology. Pharmacol Ther 119: 55-73, 2008.

35. Li B, Rosenbaum PS, Jennings NM, Maxwell KM and Roth S: Differing roles of adenosine receptor subtypes in retinal ischemia-reperfusion injury in the rat. Exp Eye Res 68: 9-17, 1999.

36. Zhong Y, Yang Z, Huang WC and Luo X: Adenosine, adenosine receptors and glaucoma: An updated overview. Biochim Biophys Acta 1830: 2882-2890, 2013. 